\title{
Causality between Foreign Remittance and Economic Growth: Empirical Evidence from Croatia
}

\author{
Craig A. Depken II ${ }^{1}$, Maja Nikšić Radić ${ }^{2, *(\mathbb{D})}$ and Hana Paleka ${ }^{2}$ \\ 1 Belk College of Business, University of North Carolina at Charlotte, Charlotte, NC 28223, USA; \\ cdepken@uncc.edu \\ 2 Faculty of Tourism and Hospitality Management, University of Rijeka, 51000 Rijeka, Croatia; \\ hberbic@hotmail.com \\ * Correspondence: majanr@fthm.hr
}

Citation: Depken, C.A., II;

Nikšić Radić, M.; Paleka, H.

Causality between Foreign

Remittance and Economic Growth:

Empirical Evidence from Croatia.

Sustainability 2021, 13, 12201.

https://doi.org/10.3390/

su132112201

Academic Editor: Roberta Arbolino

Received: 10 September 2021

Accepted: 29 October 2021

Published: 5 November 2021

Publisher's Note: MDPI stays neutral with regard to jurisdictional claims in published maps and institutional affiliations.

Copyright: (C) 2021 by the authors. Licensee MDPI, Basel, Switzerland. This article is an open access article distributed under the terms and conditions of the Creative Commons Attribution (CC BY) license (https:/ / creativecommons.org/licenses/by/ $4.0 /)$.

\begin{abstract}
While human capital and foreign capital have received considerable attention in the study of economic growth, foreign remittances are less of a focus. Though some studies have identified the increasing importance of remittances, they have failed to analyze the relationship between foreign remittances and economic growth. The aim of this paper is to investigate the causal link between foreign remittances and economic growth in the Republic of Croatia over the period from 2000q1 to 2020q2. Any causal link is identified using Granger causality tests in vector autoregression models. In addition, variance decomposition and impulse response functions help determine any dynamic links. The empirical results suggest that, in the case of Croatia, there is a unidirectional causal relationship from foreign remittances to economic growth but no link in the opposite direction. The research results indicate that foreign remittances play a role in the Croatian economy and are one of the consequences of the large emigration processes that affected Croatia after joining the European Union.
\end{abstract}

Keywords: economic growth; foreign remittance; Granger causality; impulse response function; variance decomposition

\section{Introduction}

The globalization of the world economy is a consequence of the growth in international trade growth, global capital flows and migration flows, and improvements in human capital. Before 1870, none of the categories mentioned was large enough to speak about economic globalization in a true sense [1]. The cross-border movement of goods and services, international movement of capital, and migration of people often characterizes globalization. However, in research, writing, and teaching international economics, usually only international trade and investment are adequately covered, while the third part, migration, is only superficially represented [2]. Neglecting migration is particularly noticeable in the modern era of migration. According to [3], international migration has played a crucial role in increasing the scope of international economic integration, thus playing the same role as international capital flows and cross-border movement of goods and services. It is especially important to recognize the component of foreign remittances as a direct consequence of international migration. Nevertheless, while the research into the impact of capital movements on economic growth is very thoroughly researched [4], the impact of foreign remittances on economic growth is a somewhat neglected area of research [5].

Defining foreign remittances is a complex issue related to the interpretation of remittances as income or as capital flows. According to [6], foreign remittances do not serve as development capital. Nevertheless, despite conceptual differences between foreign remittances and international capital flows, [7] consider it useful to think of foreign remittances as an increase in the available funds that can be invested in the recipient country. The authors of [8] show that foreign remittances act as a tool for development 
through investment, i.e., foreign remittances stimulate growth in financially less developed countries by enabling a substitute channel for investment financing.

However, the fact is that foreign remittances remain important capital flow nowadays. According to [9], remittances are the human face of global capital flows. Their importance is approximately equal to that of foreign direct investment (FDI) and official development assistance (ODA). All three of these capital flows have grown significantly in recent decades. According to data from the World Bank, the level of foreign remittances and FDI has become equal in middle-income countries, while foreign remittances are far larger than FDI in lower-middle-income and low-income countries.

Foreign remittances are an important component of further economic development for many countries. Compared to FDI, foreign remittances are also much more stable flows. Throughout the global financial crisis in 2008, foreign remittances experienced a minimal decline relative to FDI. In addition, remittances have shown greater resilience during the COVID-19 crisis of 2020-2021; their expected decline is approximately $20 \%$ [10]. In comparison, according to [11], FDI is expected to fall by $40 \%$, while greenfield FDI will fall by $50 \%$. According to [12], foreign remittances can also play a significant role in achieving Sustainable Development Goals.

Figure 1 depicts the ratio of remittances to GDP for Croatia and a selection of European Union member countries. It is obvious that Croatia is by far the largest recipient of foreign remittances relative to its GDP. While the EU-27 average regarding the share of foreign remittances in GDP is $0.8 \%$, Croatia's share is $6.6 \%$. The situation is even more intriguing if we compare the share of FDI and foreign remittances in the GDP of the Croatian economy, as shown in Figure 2.

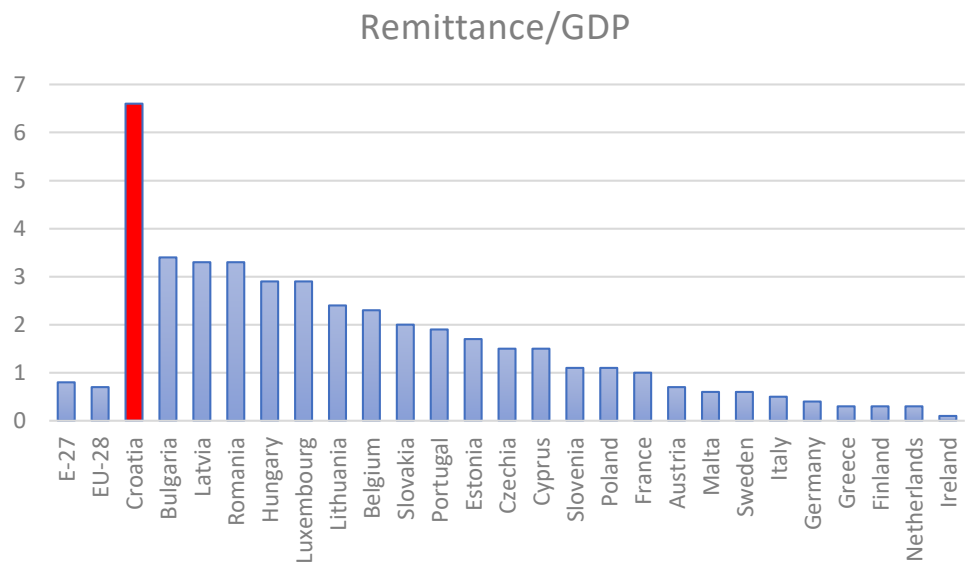

Figure 1. Inbound personal remittances in 2019 as a percentage of GDP. (Adapted from [13]).

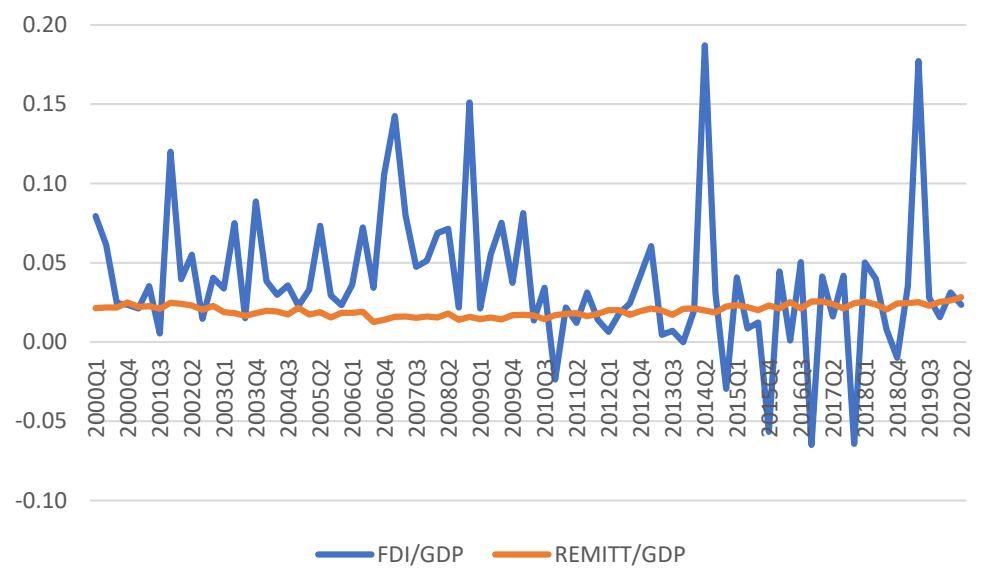

Figure 2. FDI and remittances in Croatia, as shares of GDP. (Authors' calculation using data from [14]). 
It is a curiosity that Croatia, as a high-income country, has consistently received a high level of foreign remittances as a share of GDP for the past two decades. It is also interesting that during the last decade, the share of foreign remittance in GDP was very often greater than the ratio of FDI to GDP. Comparing Croatian data with global data and other high-income countries leads to the same conclusions (see Appendix A). High-income countries, and even upper-middle-income countries, recorded a far higher level of FDI than foreign remittances throughout the same period.

Indeed, remittances to Croatia appear to be a bit of an anomaly compared to other countries. It is reported that in the first two quarters of 2021, remittances amounted to 1.745B euros whereas the nation's tourism sector generated 1.494B euros in revenues, this despite tourism in Croatia being at an all-time high in 2021 [15]. One explanation for the high remittances is the large diaspora of Croatians to Europe, the Americas, and the Middle East combined with active diaspora engagement on the part of the Croatian government [16]. One of the primary reasons for the majority of Croatians that move out of the country is poor financial situation in Croatia. Therefore, it would seem that those who move away and find greater financial success might be inclined to send remittances home.

The aim of this research is to consider the causal link between foreign remittances and GDP in the Republic of Croatia from 2000q1 to 2020q2. The research uses vector autoregression to apply Granger causality tests, impulse response functions, and variance decomposition. The empirical results suggest that there is a unidirectional causal link from economic growth to remittances but no causal link from remittances to economic growth. The results have implications for public policy and anticipation of remittances contributing to economic growth in Croatia.

\section{Theoretical Background}

The impact of remittances on economic growth, and vice versa, has a rich empirical literature. The reason for the empirical focus seems to be that the implications of remittances on economic growth can be positive or negative depending on how the remittances are used. This suggests that there is no specific theoretical solution to the question and, therefore, properly conducted empirical analysis is necessary to determine the existence and magnitude of any causal links between remittances and economic growth, and viceversa. There have been extensions to both the standard Solow growth model and the Ramsey growth model to incorporate remittances. If remittances only enter the household budget constraint, then there is no change in the saving rate and, therefore, no impact on the steady state growth rate of the country in either model. If, on the other hand, a country is converging in growth rates with other countries from "below", that is from a lower level of economic activity than other countries, then it is possible that remittances might influence productivity if they are funneled into investment that alters the path toward convergence and, therefore, would influence economic growth in the short term as the country converges with others.

Empirical research points to several channels through which foreign remittances might improve economic growth through additional foreign exchange inflows [17], finance physical capital investments, stimulating the birth of new enterprises [18], finance human capital investments by increasing health and education resources [19], as well as reduce macroeconomic volatility [20]. On the other hand, there is also empirical evidence of limited effects of foreign remittances on long-term economic growth if they are spent more on consumption than investment [21], and they act as a substitute for productive activity. According to [18], high levels of foreign remittances can trigger a vicious circle of economic stagnation and dependence, known as the "remittance trap". Foreign remittances can also lead to a slowdown in economic growth through exchange rate appreciation, negatively affecting a country's competitiveness in international trade [22].

On the other hand, economic growth may also increase foreign remittances, which appears to be counterintuitive; after all, if a country is enjoying economic growth, why do those outside of the country increase remittances? However, according to [23], 
GDP growth can attract further remittances perhaps because those outside the country feel that there are local investment and consumption opportunities. When causality goes from economic growth to remittances, it is possible that a country has invested in visible consumption, housing, and other opportunities that might not improve a country's productivity but are nonetheless attractive to those outside the country [24]. Lastly, the causality going from economic growth to foreign remittances suggests growth potential and investment opportunities in receiving countries draw an enormous flow of remittances from those outside the country [25].

To facilitate comparing the results in this paper with those in previous studies, summaries of previous research findings including the theoretical background about the relationship between foreign remittances and economic growth are listed in Table 1.

Based on the relevant literature described in Table 1, it is apparent that the results are quite contradictory regarding the relationship between remittances and economic growth. A large number of studies suggest negative $[6,26]$ as well as positive impacts of foreign remittances on economic growth [26,32].

While analyzing the impact of remittances on economic growth, authors often point out that remittances may induce economic growth through diverse channels. The authors $[8,30,34,35]$ find that remittances are a significant alternative used for investment financing, especially in surroundings where the financial sector is less developed. Conversely, several previous studies offer evidence and support for the hypothesis that remittances negatively affect the economic growth of country of origin; the work in $[6,28,36]$ found evidence of a negative and significant relationship between remittances and economic growth in the long run. The authors of [33] find that remittances Granger-cause economic growth of several but not all CEE countries. Similar ambiguous results are obtained in many other studies regarding this topic $[37,38]$.

This confusion suggests that it is not practical to use previous research results to infer what relationships might exist in Croatia between remittances and economic growth Therefore, we next turn to an empirical analysis of causality between these two variables.

Table 1. Empirical evidence on foreign remittances and economic growth causality.

\begin{tabular}{|c|c|c|c|}
\hline Authors & Sample/Period & Methodology & Results \\
\hline [6] & 113 countries / $1970-1998$ & Panel data & $\begin{array}{l}\text { The results indicate a negative effect of } \\
\text { remittances on economic growth, emphasizing } \\
\text { the moral hazard involved in remittances. }\end{array}$ \\
\hline [26] & $\begin{array}{c}11 \text { countries of } \\
\text { Eastern Europe/1990-1999 }\end{array}$ & Panel data & $\begin{array}{l}\text { Positive effect of remittances on economic } \\
\text { growth; both directly and indirectly. }\end{array}$ \\
\hline [8] & $\begin{array}{l}100 \text { developing } \\
\text { countries/1975-2002 }\end{array}$ & OLS regression & $\begin{array}{l}\text { Results demonstrate that economic growth is } \\
\text { strongly affected by remittances, especially in } \\
\text { countries with less developed financial systems. }\end{array}$ \\
\hline [27] & $\begin{array}{c}162 \text { developing } \\
\text { countries/1970-2003 }\end{array}$ & Panel data & $\begin{array}{l}\text { The remittances bias will most probably cause } \\
\text { economic growth in the long-term; especially in } \\
\text { surroundings where higher quality political and } \\
\text { economic policies and institutions are present. }\end{array}$ \\
\hline [28] & 12 CEE countries/1996-2010 & $\begin{array}{l}\text { Balanced panel } \\
\text { data }\end{array}$ & Remittances negatively affect economic growth. \\
\hline [29] & Tunisia/1970-2010 & $\begin{array}{l}\text { Autoregressive } \\
\text { distributed lag (ARDL) } \\
\text { approach }\end{array}$ & $\begin{array}{c}\text { Results point to limited support about long-run } \\
\text { causality. However, there is evidence of } \\
\text { significant bidirectional causality between } \\
\text { remittances and economic growth in the short } \\
\text { run. }\end{array}$ \\
\hline [30] & $\begin{array}{c}74 \text { developing } \\
\text { countries/1989-2015 }\end{array}$ & Regression analysis & $\begin{array}{l}\text { Remittances are positively related to economic } \\
\text { growth and private consumption expenditure. }\end{array}$ \\
\hline
\end{tabular}


Table 1. Cont.

\begin{tabular}{cccc}
\hline Authors & Sample/Period & Methodology & Results \\
\hline$[31]$ & Togo/1974-2015 & $\begin{array}{c}\text { Vector equilibrium correction } \\
\text { method }\end{array}$ & $\begin{array}{c}\text { Results indicate a long-run bidirectional Granger } \\
\text { causality between remittances and economic } \\
\text { growth. On the other hand, no evidence of } \\
\text { short-run causal relationship. }\end{array}$ \\
\hline$[32]$ & $\begin{array}{c}\text { seven countries from } \\
\text { CEE/2010-2016 }\end{array}$ & Panel data & $\begin{array}{c}\text { Economic growth is positively affected by } \\
\text { remittances. }\end{array}$ \\
\hline Romania and 11 CEE & Quntries/1996-2017 & $\begin{array}{c}\text { Quantitative } \\
\text { by using econometric } \\
\text { models }\end{array}$ & $\begin{array}{c}\text { The short-run impact of remittances on GDP was } \\
\text { found in CZE and LTU, while a long-run } \\
\text { influence was established in six CEE countries } \\
\text { (BGR, CZE, EST, HUN, LTU and LVA). }\end{array}$ \\
\hline
\end{tabular}

\section{Data and Methodological Framework}

With the aim of analyzing the causal link among variables, we collected quarterly data on foreign remittances from the Croatian National Bank and quarterly economic growth from the Eurostat database for the period 2000q1 through 2020q2. The collected data concerning gross domestic product (GDP) and the inflow of remittances (REMITT) are deflated, converted to natural logarithms and seasonally adjusted using the CENSUS-X12 procedure.

To test the hypothesis that remittances and economic growth share causal links, the vector autoregression (VAR) methodology is employed with the following two-equation model:

$$
\begin{aligned}
& \log d p_{t}=a_{0}+a_{1} \log g d p_{t-1}+\cdots+a_{p} \log g d p_{t-p}+b_{1} \operatorname{logremitt~}_{t-1}+\cdots \\
& +b_{p} \text { logremiit } t_{t-p}+u_{t} \\
& \text { logremitt }_{t}=c_{0}+c_{1} \operatorname{logremitt}_{t-1}+\cdots+c_{p} \text { logremitt }_{t-p}+d_{1} \operatorname{loggdp} p_{t-1}+\cdots \\
& +d_{p} \log g d p_{t-p}+v_{t}
\end{aligned}
$$

In the models above, loggdp and logremitt are the natural logarithms of gross domestic product and foreign remittances for the Republic of Croatia, respectively, $p$ is the optimal lag length, the $a^{\prime} \mathrm{s}, b^{\prime} \mathrm{s}, c^{\prime}$ s, and $d^{\prime}$ s are parameters to be estimated, and $u$ and $v$ are zero-mean error terms. To consider the causal relation between the variables, unit root tests are first performed, then the appropriate VAR model is estimated, and finally Granger causality tests are performed. To determine any dynamic links between foreign remittances and economic growth, impulse response functions and variance decomposition are derived to depict the relationships.

Following the existing literature, two control variables are often included in the causality model to ensure the internal validity of the empirical results: foreign direct investment stock (FDI) and gross fixed capital formation (GFCF). The GFCF is deflated, converted to natural logarithms and seasonally adjusted using the CENSUS-X12 procedure; the FDI is deflated and converted to natural logarithms. Quarterly data on GFCF is collected from the Eurostat database and quarterly FDI from the Croatian National Bank for the period 2000q1 through 2020q2. All data are expressed in millions of euros.

Granger causality tests are applied to the expanded VAR that includes the two additional control variables. The expanded VAR is specified as:

$$
\begin{aligned}
& \log g d p_{t}=a_{0}+a_{1} \log d p_{t-1}+\ldots+a_{p} \log d d_{t-p}+b_{1} \operatorname{logremitt}_{t-1}+\ldots \\
& +b_{p} \operatorname{logremitt~}_{t-p}+c_{1} \log g c f c_{t-1}+\ldots+c_{p} \log g c f c_{t-p} \\
& +d \log f d i_{t-1}+\ldots+d_{p} \log f d i_{t-p}+u_{t} \\
& \text { logremitt }_{t}=e_{0}+f_{1} \text { logremitt }_{t-1}+\ldots+f_{p} \operatorname{logremitt}_{t-p}+g_{1} \log d \mathrm{p}_{t-1}+\ldots \\
& +g_{p} \log g d p_{t-p}+h_{1} \log f d i_{t-1}+\ldots+h_{p} \log f d i_{t-p}+v_{t}
\end{aligned}
$$


In the models above, $\log g d p$, logremitt, $\log g c f c$ and $\log f d i$ are the natural logarithms of gross domestic product, foreign remittances, gross fixed capital formation, and foreign direct investment for the Republic of Croatia, respectively, $p$ is the optimal lag length, and the $a^{\prime} \mathrm{s}, b^{\prime} \mathrm{s}, c^{\prime} \mathrm{s}, d^{\prime} \mathrm{s}, e^{\prime} \mathrm{s}, f^{\prime} \mathrm{s}, g^{\prime} \mathrm{s}$ and $h^{\prime} \mathrm{s}$ are parameters to be estimated, and $u$ and $v$ are zero-mean error terms.

\section{Empirical Results}

Augmented Dickey Fuller (ADF) unit-root tests were applied to test both series for stationarity. As reported in Table 2, both series are stationary after first-differencing. As a result, both series are denoted as I (1).

Table 2. ADF test result 1.

\begin{tabular}{ccc}
\hline \multirow{2}{*}{ Variable } & Level & First Difference \\
\cline { 2 - 3 } & Constant & Constant \\
\hline $\operatorname{logg} d p$ & -2.292968 & $-3.832254^{* * *}$ \\
\hline $\log$ remitt & -0.622565 & $-11.33219^{* * *}$ \\
\hline
\end{tabular}

The significance of $p$-value: *** $p<0.01$. Lag length in the model is based on the Schwarz information criterion.

The lag optimal lag length of the VAR can be determined by minimizing the final prediction error (FPE), the Akaike information criterion (AIC), the Shwartz criterion (SC), or the Hannan-Quinn information criterion (HQ). These values, along with the loglikelihood value (LogL) and likelihood-ratio test statistics (LR), are reported in Table 3. The results suggest, according to LR and FPE, that the optimal lag length is two.

The next step in the procedure is to examine the model's dynamic stability. One way to do this is to inspect whether any of the characteristic roots fall outside the unit circle. Figure 3 demonstrates that none of the roots fall outside the unit circle, which suggests the VAR models are stable and that the results are internally valid.

The final step in this study examines Granger causality. Following the standard Granger causality methodology, for remittances and economic growth, a Wald test is to the first $p$ parameters of other variables in the VAR model. If the Wald test result is significant, this suggests rejecting the null hypothesis of no causal link. The results of the Granger causality tests are reported in Table 4 . The findings suggest no causal link between remittances and economic growth in either direction.

Following the existing literature, we repeat the same analysis but including the two additional control variables. Stationarity of the variables was tested for both control variables. The results of the unit root test (ADF test), reported in Table 5, indicate that both series are stationary after the first difference.

Table 3. Lag order selection criteria.

\begin{tabular}{ccccccc}
\hline Lag & LogL & LR & FPE & AIC & SC & HQ \\
\hline 0 & 272.4123 & NA & $1.87 \times 10^{-6}$ & -7.511453 & -7.448213 & 0 \\
1 & 278.9771 & 12.58254 & $1.75 \times 10^{-6}$ & -7.582698 & -7.392976 & 1 \\
2 & 285.3659 & 11.89031 & $1.63 \times 10^{-6}$ & -7.649054 & -7.332850 & 2 \\
3 & 288.1967 & 5.111091 & $1.69 \times 10^{-6}$ & -7.616575 & -7.173890 & 3 \\
4 & 293.3681 & 9.049891 & $1.64 \times 10^{-6}$ & -7.649113 & -7.079947 & 4 \\
5 & 296.3164 & 4.995716 & $1.69 \times 10^{-6}$ & -7.619899 & -6.924251 & 5 \\
6 & 299.4423 & 5.123083 & $1.74 \times 10^{-6}$ & -7.595620 & -6.773490 & 6 \\
7 & 299.5422 & 0.158164 & $1.94 \times 10^{-6}$ & -7.487283 & -6.538673 & 7 \\
\hline
\end{tabular}


Inverse Roots of AR Characteristic Polynomial

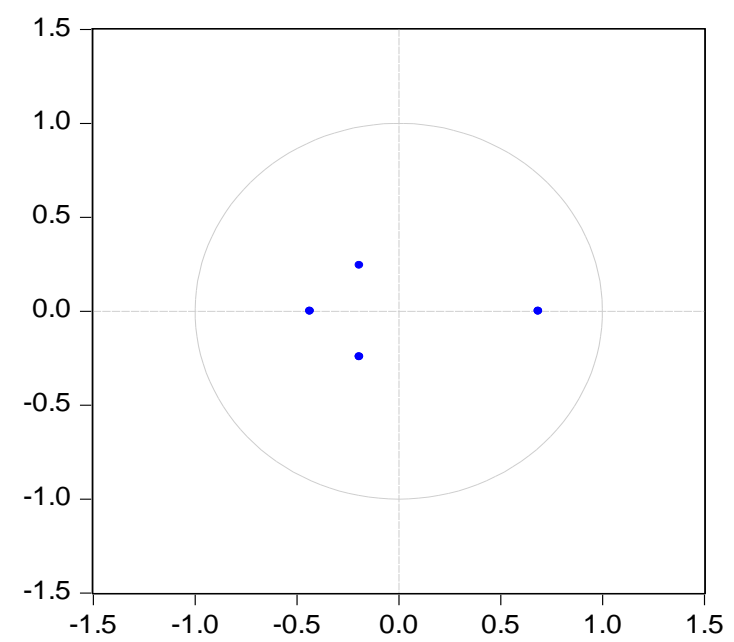

Figure 3. VAR model stability.

Table 4. Granger causality test 1.

\begin{tabular}{ccc}
\hline Causality & Chi-Sq & $p$-Value \\
\hline$g d p=>$ remitt & 0.873135 & 0.6463 \\
\hline remitt $=>g d p$ & 2.130258 & 0.3447 \\
\hline
\end{tabular}

Table 5. ADF test result 2.

\begin{tabular}{ccc}
\hline \multirow{2}{*}{ Variable } & Level & First Difference \\
\cline { 2 - 3 } & Constant & Constant \\
\hline $\log g f f f$ & -2.460988 & $-7.624597^{* * *}$ \\
\hline $\log f d i$ & -2.757498 & $-6.350376^{* * *}$ \\
\hline
\end{tabular}

The significance of $p$-value: ${ }^{* * *} p<0.01$. Lag length in the model is based on the Schwarz information criterion.

The results of the Granger causality test with the control variables are reported in Table 6.

Table 6. Granger causality test 2.

\begin{tabular}{cccc}
\hline Causality & & Chi-Sq & $p$-Value \\
\hline \multirow{3}{*}{$g d p=>$ remitt } & $g d p$ & 0.877709 & 0.6448 \\
\cline { 2 - 4 } & $f d i$ & 1.177458 & 0.5550 \\
\cline { 2 - 4 } & $g f f f$ & 0.607318 & 0.7381 \\
\cline { 2 - 4 } remitt $=>g d p$ & ALL VARIABLES & 3.004699 & 0.8083 \\
\cline { 2 - 4 } & remitt & 1.681587 & 0.4314 \\
\cline { 2 - 4 } & $f d i$ & 8.675453 & $0.0131^{* *}$ \\
\cline { 2 - 4 } & ALL VARIABLES & 1.379550 & 0.1119 \\
\hline
\end{tabular}

Note: The significance of $p$-value: ${ }^{* *} p<0.05$.

The inclusion of control variables reveals that there is a causal link from foreign remittances toward economic growth. 
Table 7 reports the results of the variance decomposition from the VAR model. The variance decomposition of the variables $g d p$ and remitt was extended for 24 months. The variance decomposition is useful in evaluating how shocks echo through a system showing the relative share of one variable in the clarification of the variance of another variable in future periods.

The variance decomposition shows that $g d p$ clarifies $100.00 \%$ of its prognostic errors during the first month. One year after, it dropped to $78.86 \%$ and stabilized around that value. Additionally, remitt, $f d i$ and $g f c f$ mark the clarification of the $g d p$ prognostic error. After the one-year period, fdi could explain $11.33 \%$, remitt $5.29 \%$ and $g f c f 4.52 \%$. The remitt variable clarifies $96.26 \%$ of its prognostic error in the first month, but after six months, this percentage falls to $80.31 \%$ but it then grows to $81.97 \%$ after the next six months.

Table 7. Variance decomposition.

\begin{tabular}{ccccccccc}
\hline \multirow{2}{*}{ Variance Period } & \multicolumn{3}{c}{ Variance Decomposition of $g d p$} & \multicolumn{4}{c}{ Variance Decomposition of remitt } \\
\cline { 2 - 9 } & $g d p$ & remitt & $f d i$ & $g f c f$ & remitt & $g d p$ & $f d i$ & $g f c f$ \\
\hline 1 & 100.00 & 0.00 & 0.00 & 0.00 & 17.18 & 82.82 & 0.00 & 0.00 \\
\hline 6 & 79.40 & 5.20 & 10.84 & 4.55 & 16.32 & 81.09 & 1.38 & 1.22 \\
\hline 12 & 78.86 & 5.29 & 11.33 & 4.52 & 16.32 & 81.08 & 1.38 & 1.22 \\
\hline 18 & 78.85 & 5.30 & 11.34 & 4.52 & 16.32 & 81.08 & 1.38 & 1.22 \\
\hline 24 & 78.85 & 5.30 & 11.34 & 4.52 & 16.32 & 81.08 & 1.38 & 1.22 \\
\hline
\end{tabular}

The fluctuation of remitt was mainly explained by the impact of $g d p$ and its own impact. The impact of $f d i$ and $g f c f$ on remitt was minimal. The variance decomposition of remitt showed that the impact of $g d p$ was substantial, after one year GDP could explain $81.08 \%$ of the variance of remitt. The impact of remitt itself after one year could explain only $16.32 \%$.

While the Granger causality tests suggest that there is a causal link from remittances to economic growth, the test alone does not indicate the qualitative relationship between the two-is it positive or negative? The impulse response functions of $g d p$ to a one-unit shock to each of the three other variables helps depict the relationship. In Figure $4 \mathrm{a}$, it is apparent that the isolated impact of remittances on $g d p$ is initially negative but tends toward zero within six quarters. On the other hand, $g d p$ responds positively to a shock to foreign direct investment, as expected, and the positive response persists until nine quarters later and is weakly statistically significant. The impact of a unit shock to gross fixed capital formation is initially positive but is statistically and economically insignificant after three quarters.

Figure $4 \mathrm{~b}$ depicts the impulse response functions for a one-unit change in $g d p, f d i$, and $g f c f$ on the dynamic reaction of remittances. While there appears to be a slight increase in remittances in the quarter following a shock to $g d p$, the impact is short-lived and is economically and statistically insignificant after the first quarter after the shock. Remittances respond in a manner that is not statistically or economically significant to unit shocks to $f d i$ or $g f c f$. 

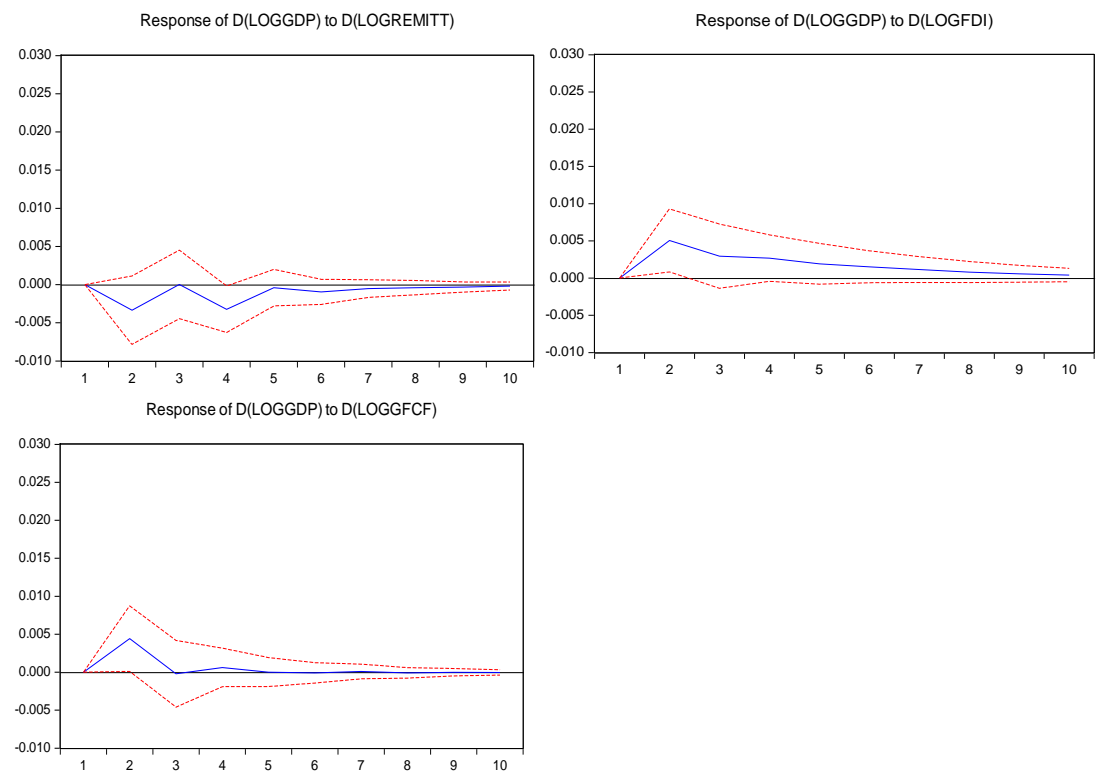

(a)
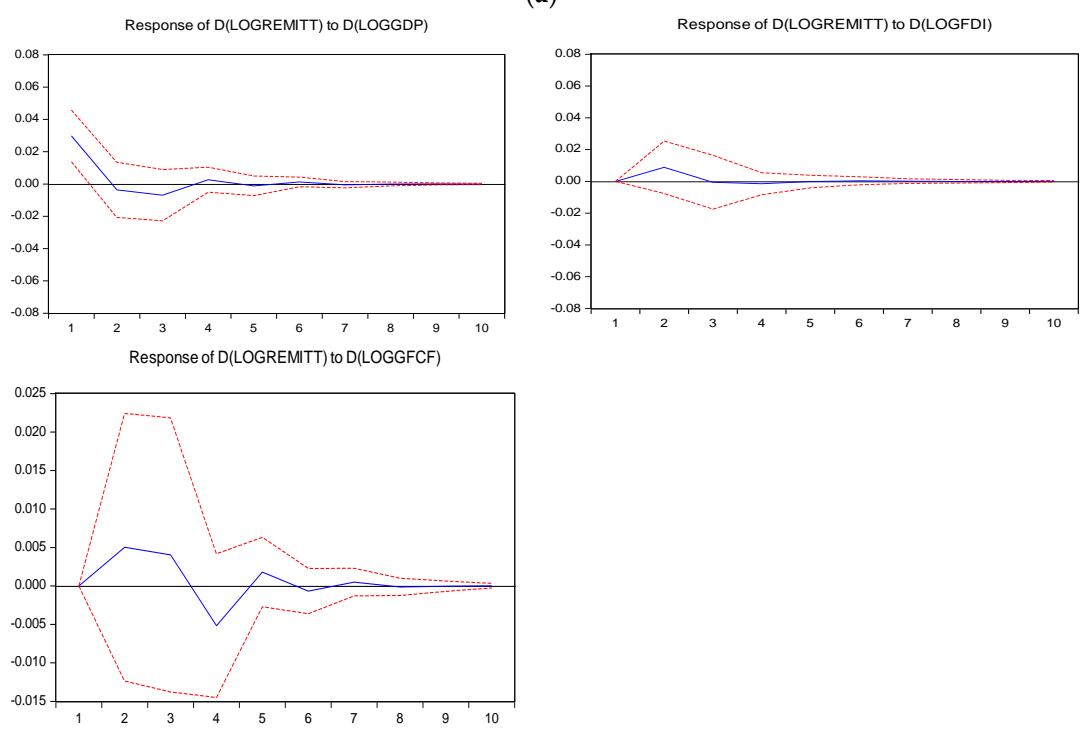

(b)

Figure 4. (a) The impulse response of GDP in Croatia. (b) The impulse response of foreign remittance in Croatia.

\section{Concluding Remarks and Policy Implications}

Economic growth is a key priority for virtually every country in the world and foreign remittances are a potentially important determinant of economic growth. However, the theoretical implications of remittances on economic growth are ambiguous, and therefore, the question of whether remittances hinder or improve economic growth is an empirical issue. The large empirical literature that investigates the impact of remittances on economic growth has not reached consensus, which suggests that it is not practical to generalize when asking about the impact of remittances on a particular country. This study contributes another investigation of the causal link between economic growth and foreign remittances for the Republic of Croatia over the period of 2000 through 2020.

One reason to focus on Croatia is that it is somewhat unique among developed countries in that it has a large diaspora that actively sends remittances at increasing rates over time. Indeed, in the first two quarters of 2021, remittances to Croatia were larger than the total revenue generated by Croatia's largest sector, tourism. Furthermore, remittances are also larger than foreign direct investment flows into Croatia. Thus, there is an open 
question of whether remittances are enhancing economic growth in Croatia and, perhaps, that there is reverse causation from economic growth to remittances if those in the Croatia diaspora view Croatia as a promising investment opportunity.

The empirical results suggest that in Croatia, there is a unidirectional causality from foreign remittances towards economic growth but that there is no causal link in the reverse direction; there is no Granger causality from economic growth to foreign remittances. Further analysis of variance decomposition of a four-variable VAR (including GDP, remittances, foreign direct investment, and gross fixed capital formation) suggests that the impact of a shock to remittances on GDP is relatively short-lived, especially compared to the impact of a shock to foreign direct investment and gross fixed capital formation. On the other hand, while there appears to be a one-quarter bump in remittances after a unit shock to Croatian GDP, there is no economic or statistically significant impact of foreign direct investment or gross fixed capital formation on foreign remittances to Croatia.

These empirical results suggest that policy makers would do well to continue the national government's efforts to cultivate relationships with the Croatian diaspora and to encourage the continued trend in increased remittances in the future, either to family or charitable organizations. Given the empirical results herein, another important political implication arises. Foreign remittances increase aggregate demand through an increase in personal consumption and individual investments by recipients of foreign remittances. Consequently, the multiplier effects of aggregate demand can also affect aggregate supply. It is up to political authorities to ensure a stable and stimulating macroeconomic environment.

Author Contributions: All authors have equally contributed to this work. All authors have read and agreed to the published version of the manuscript.

Funding: This work was supported by the University of Rijeka under Grant ZP UNIRI 8/18.

Institutional Review Board Statement: Not applicable.

Informed Consent Statement: Not applicable.

Data Availability Statement: Not applicable.

Conflicts of Interest: The authors declare no conflict of interest. The funders had no role in the design of the study; in the collection, analyses, or interpretation of data; in the writing of the manuscript, or in the decision to publish the results.

\section{Appendix A}

Figure A1 plots personal remittances, foreign direct investment, and net official devlolpment assistance for upper-middle income countries. As can be seen, foreign direct investment is consistently higher than remittances and official development assistance for upper-middle income countries, contrary to the Croatian experience over the same period.

Figure A2 plots personal remittances, foreign direct investment, and net official development assistance for high-income countries. As can be seen, foreign direct investment is consistently higher than remittances and official development assistance for high-income countries, contrary to the Croatian experience over the same period. 


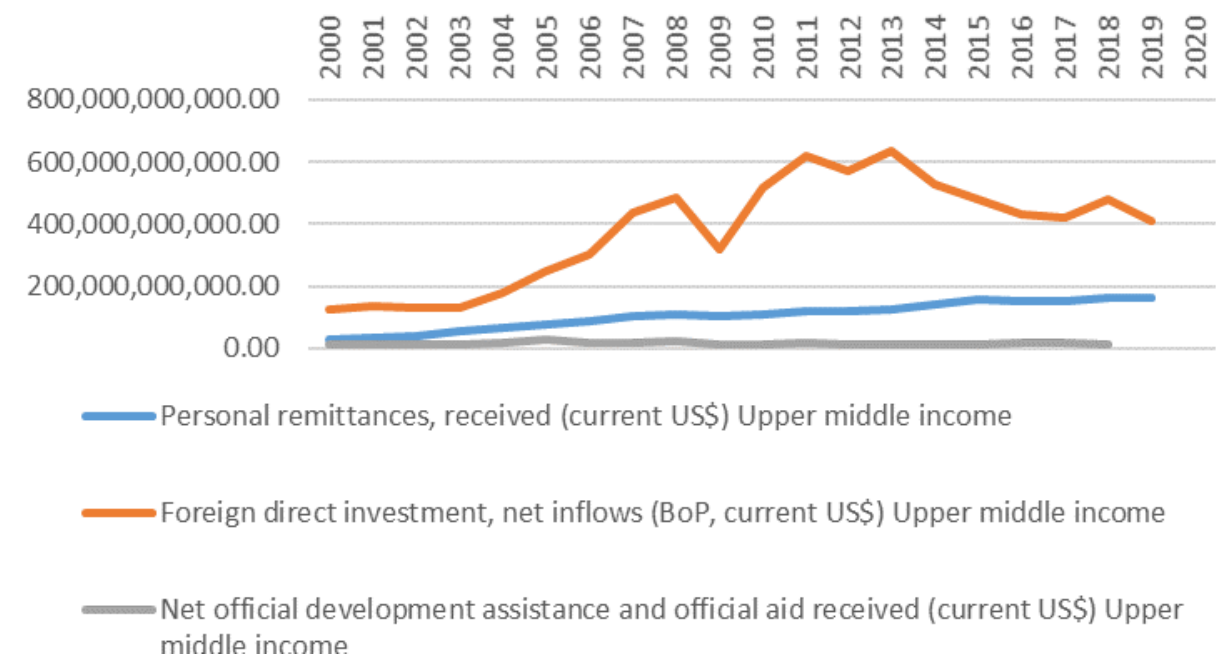

Figure A1. FDI vs. remittance vs. official development assistance for upper-middle income countries. Source: authors' calculation using [39].

Upper middle income

Personal remittances, received (current US\$̦) Upper middle income

Foreign direct investment, net inflows (BoP, current US\$̦) Upper middle income

Net official development assistance and official aid received (current US\$) Upper middle income

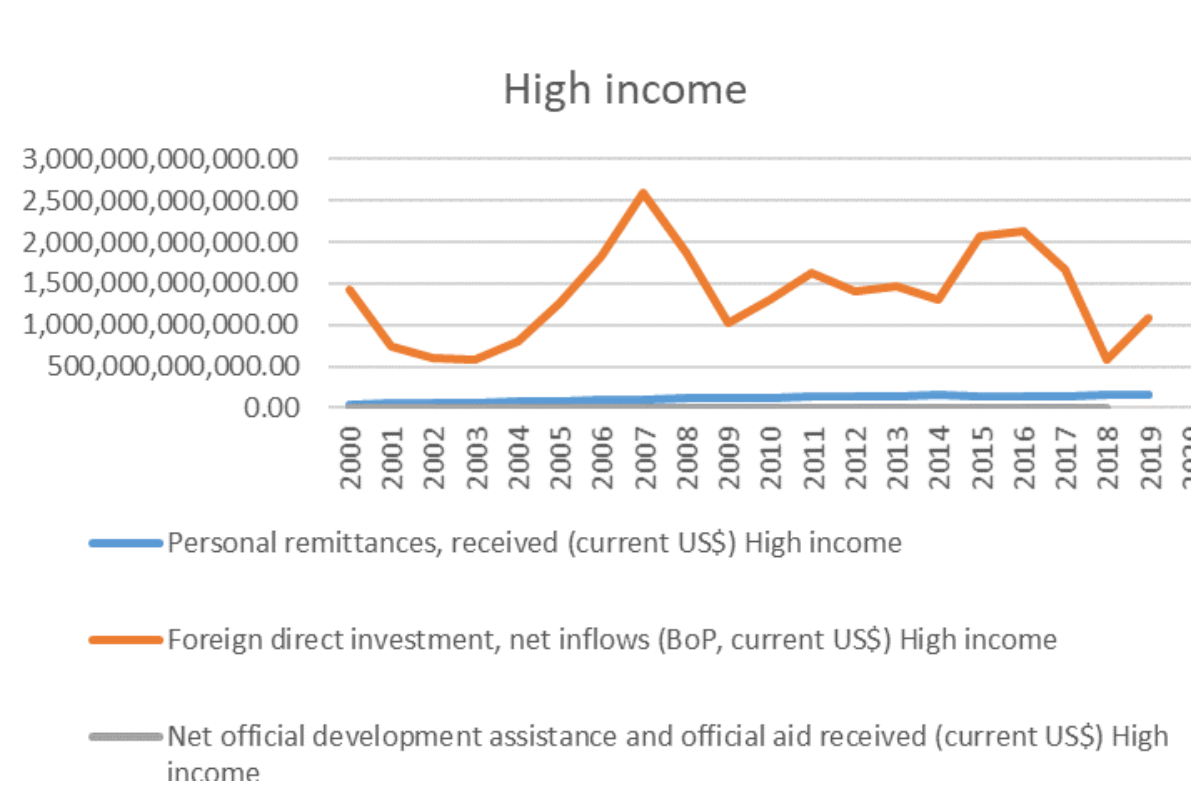

Figure A2. FDI vs. remittance vs. official development assistance for high income countries. Source: authors' calculation using [39].

\section{References}

1. World Bank. Globalization, Growth, and Poverty: Building an Inclusive World Economy; World Bank Policy Research Report, World Bank and Oxford University Press: Washington, DC, USA, 2002; Available online: https://openknowledge.worldbank. org/handle/10986/14051 (accessed on 3 October 2020).

2. Bodvarsson, Ö.B.; Van den Berg, H. The Economics of Immigration, Theory and Policy, 2nd ed.; Springer: New York, NY, USA, 2013.

3. White, R.; Tadesse, B. International Migration and Economic Integration. Understanding the Immigrant-Trade Link; Edward Elgar Publishing Limited: Cheltenham, UK, 2011.

4. Alfaro, L.; Chanda, A.; Kalemli-Ozcan, S.; Sayek, S. FDI and economic growth: The role of local financial markets. J. Int. Econ. 2004, 64, 89-112. [CrossRef]

5. Driffield, N.; Jones, C.M. Impact of FDI, ODA and Migrant Remittances on Economic Growth in Developing Countries: A Systems Approach. Eur. J. Dev. Res. 2013, 25, 173-196. [CrossRef]

6. Jahjah, S.; Chami, R.; Fullenkamp, C. Are Immigrant Remittance Flows a Source of Capital for Development. IMF Work. Pap. 2003, 3, 1. [CrossRef] 
7. Buch, C.M.; Kuckulenz, A.; Le Manchec, M.H. Worker Remittances and Capital Flows; Kiel Working Paper No. 1130; Institute for the World Economy (IfW): Kiel, Germany, 2002.

8. Giuliano, P.; Ruiz-Arranz, M. Remittances, financial development, and growth. J. Dev. Econ. 2009, 90, 144-152. [CrossRef]

9. Cocco, F.; Wheatley, J.; Pong, J.; Blood, D.; Rininsland, A. Remittances: The Hidden Engine of Globalization. Financial Times. 20 August 2019. Available online: https:/ /ig.ft.com/remittances-capital-flow-emerging-markets/ (accessed on 10 April 2020).

10. Ong, R. World Bank Predicts Sharpest Decline of Remittances in Recent History. World Bank Press Release. 2020. Available online: https: / / www.worldbank.org/en/news/press-release/2020/04/22/world-bank-predicts-sharpest-decline-of-remittancesin-recent-history (accessed on 2 September 2020).

11. UNCTAD. World Investment Report 2020: International Production Beyond Pandemic; UNCTAD: New York, NY, USA; Geneva, Switzerland, 2020.

12. United Nations. Remittances and The SDGs. Available online: https://www.un.org/en/observances/remittances-day/SDGs (accessed on 1 December 2020).

13. Eurostat Database. 2019. Available online: https://ec.europa.eu/eurostat/statistics-explained/index.php?title=File:Inbound_ personal_remittances,_2019_(\%25_of_GDP).png\#filelinks (accessed on 15 April 2020).

14. Croatian National Bank. 2021. Available online: https://www.hnb.hr/ (accessed on 15 April 2021).

15. Glas, I. The Money Sent by Guest Workers in Croatia Exceeded the Earnings from Foreign Tourists by 23.5 Percent. 2021. Available online: https: / / www.glasistre.hr/hrvatska/-novac-koji-salju-gastarbajteri-u-hrvatskoj-premasio-zaradu-od-stranih-turistaza-235-posto-749835 (accessed on 10 October 2021).

16. Garding, S. Weak by design? Diaspora engagement and institutional change in Croatia and Serbia. Int. Politi Sci. Rev. 2018, 39, 353-368. [CrossRef]

17. Amuedo-Dorantes, C.; Pozo, S. Remittance Receipt and Business Ownership in the Dominican Republic. World Econ. 2006, 29, 939-956. [CrossRef]

18. Chami, R.; Ernst, E.; Fullenkamp, C.; Oeking, A. Is There a Remittance Trap? IMF Financ. Dev. 2018, 55, 44-47.

19. Azizi, S. The impacts of workers' remittances on human capital and labor supply in developing countries. Econ. Model. 2018, 75, 377-396. [CrossRef]

20. Hosny, A. Remittance Concentration and Volatility: Evidence from 72 Developing Countries. Int. Econ. J. 2020, 34, 553-570. [CrossRef]

21. Feeny, S.; Iamsiraroj, S.; McGillivray, M. Remittances and Economic Growth: Larger Impacts in Smaller Countries? J. Dev. Stud. 2014, 50, 1055-1066. [CrossRef]

22. Ratha, D. The Impact of Remittances on Economic Growth and Poverty Reduction; Policy Brief. No. 8; Migration Policy Institute: Washington, DC, USA, 2013.

23. Das, A.; Paul, B.P. Openness and growth in emerging Asian economies: Evidence from GMM estimations of a dynamic panel. Econ. Bulletin. 2011, 31, 2219-2228.

24. Dhungel, K.R. Does remittance in Nepal cause gross domestic product? An empirical evidence using vector error correction models. Int. J. Econom. Financ. Manag. 2014, 2, 168-174.

25. Olayungbo, D.O.; Quadri, A. Remittances, financial development and economic growth in sub-Saharan African countries: Evidence from a PMG-ARDL approach. Financ. Innov. 2019, 5, 9. [CrossRef]

26. Leon-Ledesma, M.; Piracha, M. International Migration and the Role of Remittances in Eastern Europe. Int. Migr. 2004, 42, 65-83. [CrossRef]

27. Catrinescu, N.; Leon-Ledesma, M.; Piracha, M.; Quillin, B. Remittances, Institutions, and Economic Growth. World Dev. 2009, 37, 81-92. [CrossRef]

28. Gjini, A. The Role of Remittances on Economic Growth: An Empirical Investigation Of 12 CEE Countries. Int. Bus. Econ. Res. J. (IBER) 2013, 12, 193-204. [CrossRef]

29. Jouini, J. Economic growth and remittances in Tunisia: Bi-directional causal links. J. Policy Model. 2015, 37, 355-373. [CrossRef]

30. Simionescu, L.N.; Dumitrescu, D. Migrants Remittances Influence on Fiscal Sustainability in Dependent Economies. Amfiteatru Econ. 2017, 19, 640-653.

31. Ahmed, F.; Hakim, M. The Relationship between Remittances and Economic Growth in Togo: A Vector Equilibrium Correction Mechanism. Glob. Econ. Financ. J. 2017, 10, 1-11. [CrossRef]

32. Comes, C.-A.; Bunduchi, E.; Vasile, V.; Stefan, D. The Impact of Foreign Direct Investments and Remittances on Economic Growth: A Case Study in Central and Eastern Europe. Sustainability 2018, 10, 238. [CrossRef]

33. Cismas, L.M.; Curea-Pitorac, R.I.; Vădăsan, I. The impact of remittances on the receiving country: Some evidence from Romania in European context. Econ. Res. Ekon. Istraž. 2020, 33, 1073-1094. [CrossRef]

34. Aggarwal, R.; Peria, M.S.M. Do Workers' Remittances Promote Financial Development? In World Bank Policy Research Working Paper No. 3957; World Bank: Washington, DC, USA, 2006; Available online: https:/ / ssrn.com/abstract=923264 (accessed on 25 April 2020).

35. Gupta, S.; Pattillo, C.A.; Wagh, S. Effect of Remittances on Poverty and Financial Development in Sub-Saharan Africa. World Dev. 2009, 37, 104-115. [CrossRef]

36. Amuedo-Dorantes, C.; Pozo, S. Workers' Remittances and the Real Exchange Rate: A Paradox of Gifts. World Dev. 2004, 32, 1407-1417. [CrossRef] 
37. Siddique, A.; Selvanathan, E.A.; Selvanathan, S. Remittances and Economic Growth: Empirical Evidence from Bangladesh, India and Sri Lanka' Department of Economics; Discussion Paper 10.27; University of Western Australia: Perth, Australia, 2010; Available online: https:/ / www.business.uwa.edu.au/_data/assets/pdf_file/0006/1371948/10-27-Remittances-and-Economic-Growth. pdf (accessed on 30 October 2020).

38. Jawaid, S.T.; Raza, S.A. Workers' remittances and economic growth in China and Korea: An empirical analysis. J. Chin. Econ. Foreign Trade Studies 2012, 5, 185-193. [CrossRef]

39. World Bank Database. Available online: https:// data.worldbank.org/ (accessed on 20 April 2020). 